\title{
Ethnobotanical and ethnomedicinal analysis of wild medicinal plants traditionally used in Naâma, southwest Algeria
}

\author{
Miloud Bouafia $^{1,2,6}$ (D) Fouzia Amamou ${ }^{3}$ (D) $\cdot$ Mohamed Gherib $^{2} \cdot$ Mohammed Benaissa $^{4} \cdot$ Rachid Azzi $^{1}$ (D) . \\ Saïd Nemmiche 5
}

Received: 10 February 2021 / Revised: 13 May 2021 / Accepted: 18 May 2021 / Published online: 11 June 2021

(c) Society for Plant Research 2021

\begin{abstract}
Algerian people largely rely on traditional medicine practices as part of a community's identity. This first ethnobotanical study aimed to quantify and document the wild medicinal plant taxa from four family and the related traditional knowledge in Naâma province, Algeria. The survey was carried out between 2018 and 2020. The socio-demographic data and the use of medicinal species were recorded and collected randomly from 84 indigenous people using pre-prepared questionnaire. The result was evaluated using quantitative indices. A total of 27 medicinal plant species belonging to 21 genera used in the community were mostly recorded. The most represented families were Lamiaceae and Asteraceae (12 species for each of them). The aerial parts were the most frequently used plant part (73\%), while a decoction (34\%), and infusion (31\%) were the major modes of remedy preparation. The species with high UV were Rosmarinus officinalis L. (0.80), Artemisia herba-alba Asso (0.76), and Juniperus phoenicea L. subsp. phoenicea (0.75). Species with highest FL were: Ephedra alata subsp. alenda (Stapf) Trab (100\%), Teucrium polium L. (60\%), and Ballota hirsuta Benth (57.14.5\%). Atractylis caespitosa Desf and Nepeta nepetella subsp.amethystina (Poir.) Briq were newly cited as medicinal plants and have not been recorded previously in Algeria. Artemisia herba-alba Asso and Thymus algeriensis Boiss. \& Reut were reported to treat COVID-19 symptoms. The results obtained indicate the richness of the area with medicinal plants as well as knowledge of alternative medicine. The most cited plants could be contained molecules that can be tested for therapeutic uses.
\end{abstract}

Keywords Medicinal plants · Traditional medicine $\cdot$ Ethnobotanical $\cdot$ Naâma

Miloud Bouafia

miloudbio@gmail.com

Fouzia Amamou

amamoufouzia@gmail.com

Mohamed Gherib

gmnaama64@gmail.com

Mohammed Benaissa

ben_forets@yahoo.fr

Rachid Azzi

rachidbio@yahoo.fr

Saïd Nemmiche

snemiche@hotmail.com

1 Laboratory of Antifungal, Antibiotic, Physico-chemical, Synthesis and Biological Activity, Faculty of SNV-STU, University of Tlemcen, BP 119, Imama, 13000 Tlemcen, Algeria
2 Laboratory of Sustainable Management of Natural Resources in Arid and Semi-Arid Zones, University Center of Naâma, BP 66, 45000 Naâma, Algeria

3 Laboratory of Natural Products, Faculty of SNV-STU, LAPRONA, University of Tlemcen, BP 119, Imama, 13000 Tlemcen, Algeria

4 Laboratory of Ecology and Management of Natural Ecosystems, Faculty of SNV-STU, University of Tlemcen, BP 119, Imama, 13000 Tlemcen, Algeria

5 Department of biology, Faculty of Nature and Life Sciences, University of Mostaganem, Mostaganem, Algeria

6 Present Address: Department of Biology, Faculty of Natural Sciences and Life Sciences of the Earth and the Universe, University of Abou Bekr Belkaid, BP 119, Tlemcen, Algeria 


\section{Introduction}

In Algeria, traditional medicine practices are linked to the history of Arab-Muslim medicine in the Maghreb (North Africa). These practices are a model of transmission of Arab-Muslim medicine. Some therapeutic uses are transmitted directly from religious texts and are still relevant as hijâma (Cupping therapy), Ruqyah (Reciting Quran), and phytotherapy (Saad and Said 2010).

Phytotherapy is known since antiquity as the most easily accessible resource and the basis of health care; has evolved across the ages to become an important knowledge of drug discovery. However, no official strategic plan (regulatory or legislative) has been developed in the country for the integration of traditional medicine into the health care system. The Algerian Public Health Code of 23 October 1976 (158) rendered the practice of medicine without a license an offense; apart from Sec. 364 on the practice of herbalists, no exceptions were made for the practice of traditional medicine (WHO 2001). On other hand, the production and marketing of herbal drugs are permissible to a small extent. More than twenty herbal drug products are commercialized in the pharmaceutical market of Algeria (Bouzabata 2017). Due to the geographical position in the south Mediterranean basin, Algeria with its spacious area is characterized by several climatic regions and diversified vegetation; more than 3139 species of wild and naturalized plants growing in the country become part of a community's identity. Algerian people used part of these species for different purposes, which are reflected in the widespread use of medicinal plants by herbalists, healers, and people to treat several diseases (Miara et al. 2018). Nevertheless, many geographical regions and ethnic communities in this country like the province of Naâma (South-West of Algeria) have still not been explored. It has a reserve of medicinal species, a background of practice in traditional medicine for humans. Unfortunately, the indigenous knowledge of plants in Naâma and other provinces is inherited and transmitted orally from one generation to the next which makes them vulnerable to loss; Besides, the new generation is not interested to archive it from the older generation (Bouasla and Bouasla 2017).

Ethnobotany carrying great importance for several fields and the most ethnobotany's contributions and challenges are to close the gap between researcher and indigenous knowledge, to understanding how humans perceive their standing within nature, to boost methodological methods to explore plants from diverse disciplines, and to promote inter-generational continuity (Rodríguez-Calderón et al. 2019). Many ethnobotanical studies were undertaken in the Mediterranean region, especially in Algeria have warned against losing some traditional medicinal knowledge. In this framework, there is an urgent need for studying, recording, and sharing this heritage using an ethnobotanical approach survey to protect it. (Tuttolomondo et al. 2014; Bouasla and Bouasla 2017; Eddouks et al. 2017).

This study aimed to document the ethnobotanical knowledge focusing on ethnomedicine in Naâma province, a strategic region of southwest Algeria, bordered by Morocco. We inventoried, for the first time, all medicinal plants taxa from Lamiaceae, Asteraceae, Cupressaceae, and Ephedraceae using as medicine. The traditional therapeutics were documenting and analyzing using quantitative indices. Data were compared to historical literature carried out in Algeria and the Mediterranean basin.

\section{Materials and methods}

\section{Survey area}

Naâma province is located in the southwest of Algeria ( $\mathrm{N}$ $33^{\circ} 26^{\prime}$, W $0^{\circ} 54^{\prime}$ ) (Fig. 1). It is part of the Western Highlands, covers an area of $29.514 \mathrm{Km}^{2}$. It has an estimated population of 192.891 with an average density of about $6.5 \mathrm{Hab} /$ $\mathrm{Km}^{2}$. The area is characterized by an ecological diversity represented by three principal regions: steppe, mountain, and pre-Saharan with $74 \%, 12 \%$, and $14 \%$ of the total area respectively. The climatic year is divided into two main seasons: cold and relatively rainy from November to April, hot and dry from May to October. The rainfall remains weak and irregular in comparison to the north bordering provinces; the temperature ranging from $8{ }^{\circ} \mathrm{C}$ in December/January to $31.5^{\circ} \mathrm{C}$ in July/August (www.andi.dz/PDF/monographies/ NAAMA.pdf).

\section{Data collection}

This survey has been done between 2018 and 2020. A total of 84 people were face to face interviews, all people interviewed had been informed about the objective of this study. A semi-structured questionnaire interview was used to record socio-demographic data (gender, age, educational level) and the use of medicinal species (vernacular names, illnesses treated, part used, method of preparation). The plant name has been checked with the plant list database (http://www.theplantlist.org) and the African plant database (http://www.ville-ge.ch/musinfo/bd/cjb/africa/recherche. php). Voucher specimens were confirmed by experimenting botanists and stored in the herbarium of the laboratory of antifungal, antibiotic, Physico-chemical, synthesis, and biological activity, Abou Bekr Belkaid University, Tlemcen, Algeria. 


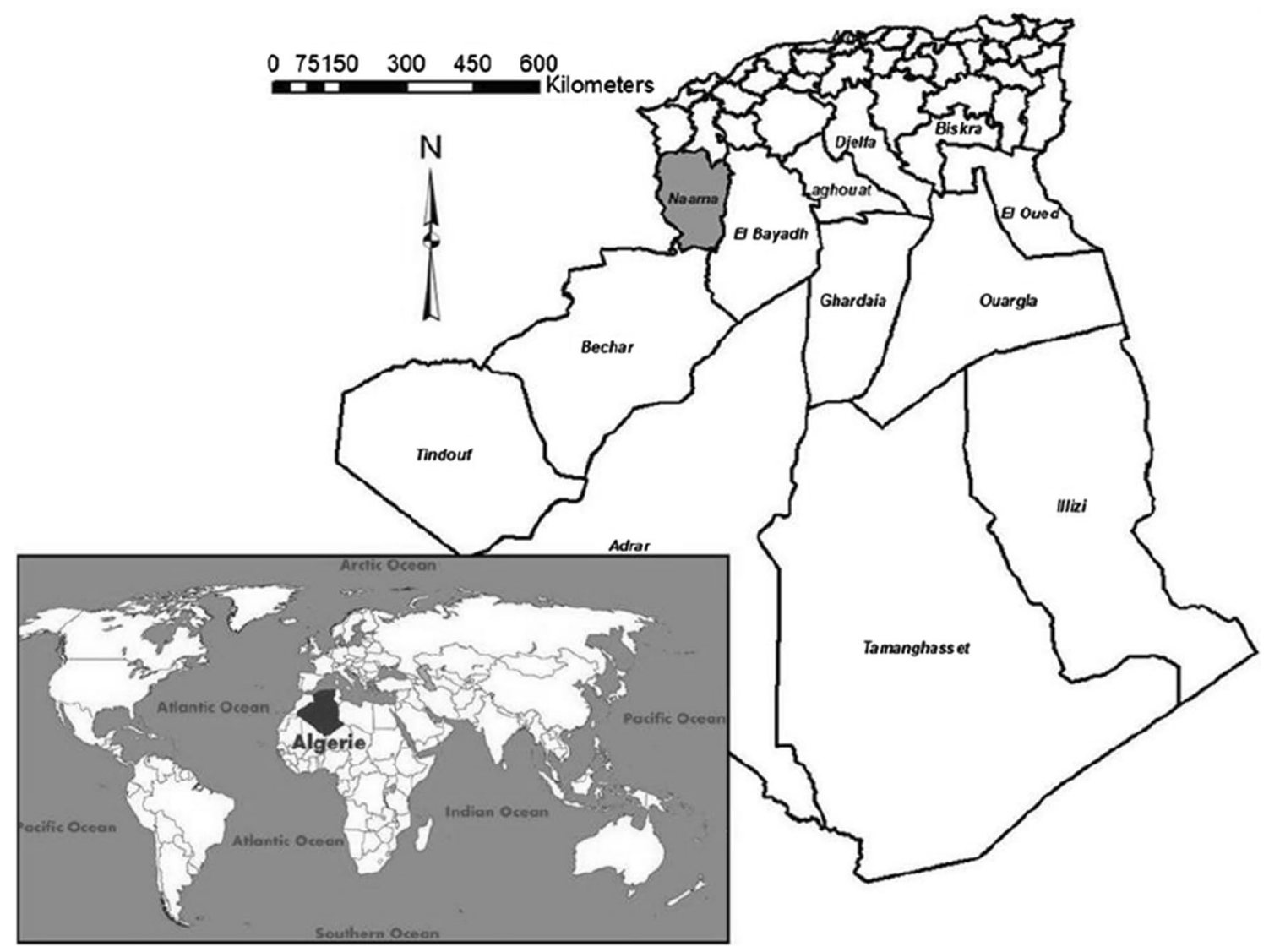

Fig. 1 Location map of study area

\section{Data analysis}

\section{Family use value (FUV)}

The FUV was calculated using this formula: $F U V=\Sigma U V s /$ ns; where $\Sigma U V$ s is the sum of use value of the species within a family and ns is the total number of species within the same family. The FUV is calculated to identify the importance of plant families (Eddouks et al. 2017).

\section{Use value (UV)}

The particular use of UV is to determine the relative significance of the local species. It was used to define the most cited plant species to treat a disease category. UV was calculated using this formula: $U V=\Sigma U i / N$; where $U i$ : number of uses reports per species, and $\mathrm{N}$ : total number of informants (Trotter and Logan 1986).

\section{Fidelity level (FL)}

The FL value is calculated to estimate the importance of the species for a given purpose. A higher fidelity level (FL) can show that the utilization of plant for specific therapeutic purposes is preferred if respondents cited it frequently. FL was calculated using the following formula: $F L=(\mathrm{Np} / \mathrm{N}) \times$ 100; where $\mathrm{Np}$ : is the number of respondents that recommended the use of the plant for a specific disease, and $\mathrm{N}$ is the number of respondents that suggested the plant for various illnesses (Phillips 1996).

\section{Results and discussion}

\section{Informants' sociodemographic profile}

In this study 84 people were questioned (Table 1), women are more interested in traditional medicine $(57.14 \%)$ compared with men. This predominance of women can be explained by their responsibility towards the family in caring for the health of family members, particularly children (Miara et al. 2018). The age range over 60 years is the most frequency range $(25 \%)$. Older people have more knowledge and experience than the younger due to the inherent belief that phytotherapy is effective and safe. The younger 
Table 1 Use of medicinal plants according to socio-demographic factors

\begin{tabular}{lll}
\hline & Total & Percentage \\
\hline Gender & 36 & \\
Male & 48 & 42.85 \\
Female & & 57.14 \\
Marital status & 11 & \\
Single & 73 & 13.1 \\
Married & & 86.9 \\
Age groups & 5 & \\
$<$ 20 & 9 & 6 \\
20-29 & 14 & 11 \\
30-39 & 16 & 17 \\
$40-49$ & 19 & 19 \\
50-59 & 21 & 23 \\
$>60$ & & 25 \\
Educational level & 34 & \\
Illiterate & 17 & 40.48 \\
Primary & 21 & 20.24 \\
Lyceum & 12 & 25 \\
University & & 14.29 \\
\hline
\end{tabular}

generation consuming wild species plants as remedies is on the way of extinction due to their interest in modern medicine.

\section{Part used}

The aerial parts $(73 \%)$ were more used than the other parts, followed by roots (18\%), and leaves (9\%). Boudjelal et al. (2013) have also registered that the aerial parts are the most used in M'Sila, while other studies reported leaves as the predominant plant part used in surveyed regions of Algeria (Benarba et al. 2015; Bouasla and Bouasla 2017; Miara et al. 2018). It is well known that bioactive principles are contained in the plant's organs with different concentrations. People in Naâma employ the aerial part based on their traditional heritage which can explain the most uses of this part by the local population.

\section{Method of preparation}

The local population uses different forms of preparation. The decoction $(34 \%)$ is the most common traditional method described to extract active compounds followed by infusion $(31 \%)$, powdering $(20 \%)$, maceration $(12 \%)$, and cataplasme (3\%). According to Meriem and Hayet (2019), decoction is the method of choice when working with tough and fibrous plants, barks, and roots and with plants that have water-soluble chemicals.

\section{Frequency of families and their use value}

Altogether, 27 plant species and 21 genera belonging to plant families Lamiaceae, Asteraceae, Cupressaceae, and Ephedraceae used against several diseases in the community are recorded (Table 2). The most represented families were Lamiaceae and Asteraceae (12 species for each of them), followed by Cupressaceae ( 2 species), and Ephedraceae (1 species). On the contrary, Ephedraceae (0.56) had a high FUV, followed by Cupressaceae (0.45), Asteraceae (0.36), and Lamiaceae (0.35) (Table 2). Our result indicates that the families which have high FUVs are not necessarily represented by a large number of species in the study area. It confirmed that the use-value of families relies on the preference of the local population to use some plants' families more than others..

\section{Medicinal plants used}

Species with high used values (UV) were Rosmarinus officinalis L. (0.80), Artemisia herba-alba Asso (0.76), Juniperus phoenicea L. subsp. phoenicea (0.75). This means that these species are the most important medicinal plants used in folk medicine by the population of Naâma to treat ailments, which might be due to their vast distribution in the area study.

In our research area, the use of $R$. officinalis L. was recorded especially to treat respiratory system problems such as cough, influenza, cold; it is also used for rheumatism, muscle spasm, cholelithiasis, cholagogue, and fever. In the traditional pharmacopeia of Algeria, the same species was recorded as an anti-diabetic, antitumoral, antihypertension, and for treating hepatic diseases (Boudjelal et al. 2013). The most effective bio-active secondary metabolites of $R$. officinalis L. were phenolic acids, diterpenes, and triterpenes phenolic. Among the isolated phenolic compounds, carnosic acid, carnosol acid, ursolic acid, and rosmarinic acid have been recorded to have major pharmacological effects (Tomi et al. 2016). These compounds except rosmarinic acid increased hPXR (human Pregnane X receptor) target gene expression, transactivated the ligand-binding domain of hPXR and recruited steroid receptor coactivator (SRC)-1, SRC-2, and SRC-3 to the ligand-binding domain of hPXR. The hPXR plays important role in the control of many gene expression linked to inflammatory processes (Seow and Lau 2017).

The most important therapeutic uses of Artemisia herbaalba Asso were those of gastric disorders, liver problems, wormer, muscle spasm, cardiac problems, and hypertension. In Algeria, it is reported to treat digestive system problems (Boudjelal et al. 2013; Miara et al. 2018, 2019a), diabetes (Bouasla and Bouasla 2017), cancer, and respiratory system diseases (Ouelbani et al. 2016). The properties of this plant 


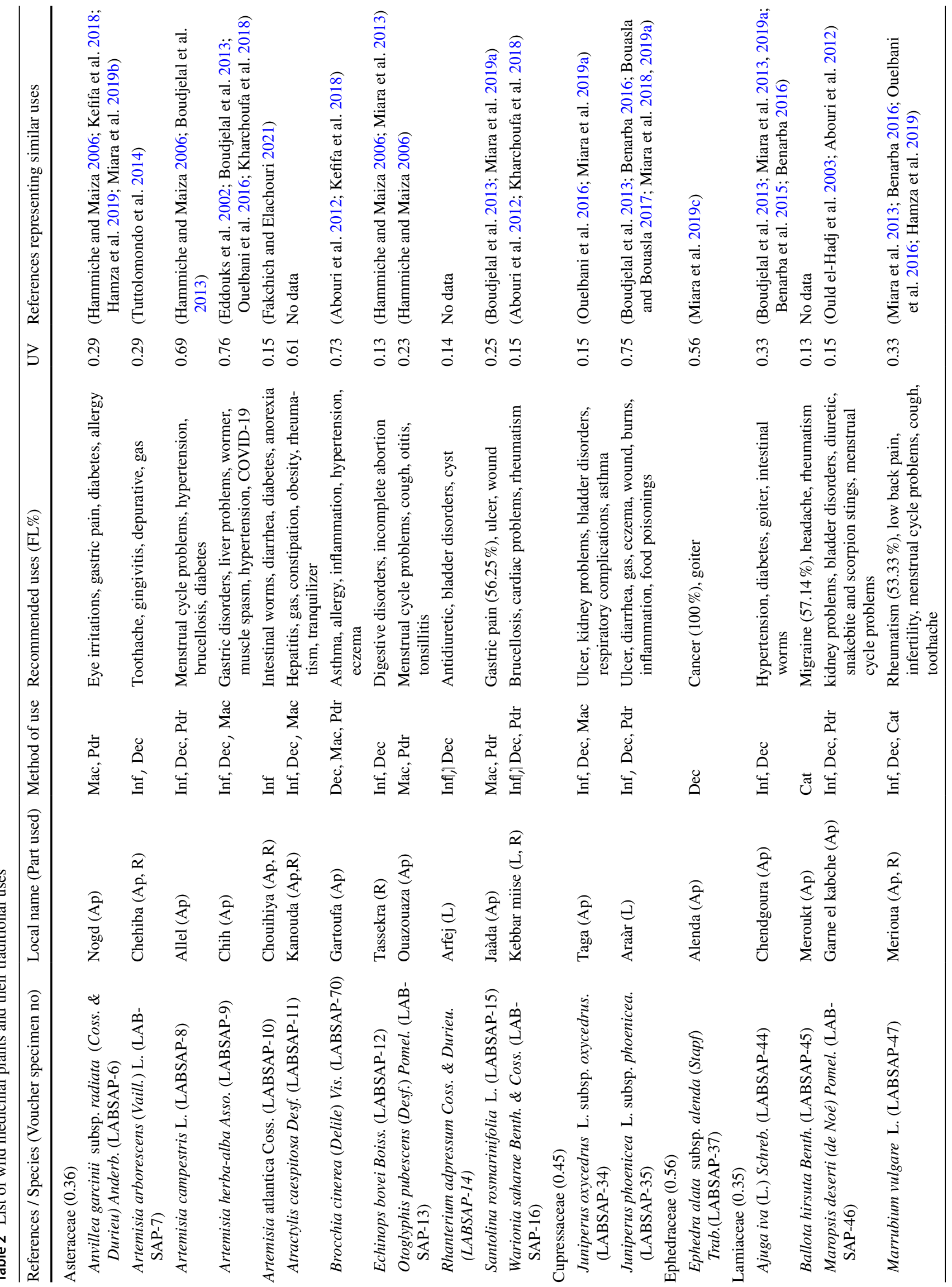


may be due to its chemical compounds as monoterpenoids, sesquiterpenoids (largely in essential oils), flavonoids, and phenolic compounds (Khlifi et al. 2013; Mohamed et al. 2019) Several studies studied the antispasmodic activity of the essential oil extracted from the plant's aerial parts. It was found that the administration of this oil relaxed the spontaneous tonus of the rabbit jejunum and reversed the tonic contraction of rat jejunum induced by carbachol (Aziz et al. 2012). Another published study has found that the aqueous extract of this plant has increased the time of gastrointestinal transit in alloxan-treated rabbits and mice (Marrif et al. 1995), and improves insulin sensitivity and hepatic steatosis in rodents-induced metabolic syndrome (Réggami et al. 2019). The same extract at a dose of $150 \mathrm{mg} / \mathrm{kg}$ for 20 days significantly reduced the systolic blood pressure in spontaneously hypertensive rats (Zeggwagh et al. 2008).

Recently, the use of Artemisia herba-alba Asso extract to treat the symptom of COVID-19 is under-discussed. Our informants found the effective use of the plant combined with Thymus algeriensis Boiss.\& Reut against COVID-19 in the early stage. It is necessary to emphasize that no published data based on clinical experience are supporting the use of these plants, and their effectiveness against coronavirus is unknown. the beneficial effects of Artemisia herbaalba Asso are probably due to its flavonoids as Artemisinin and others. The safe toxicity profile of artemisinin and its immunomodulatory properties on inflammatory diseases and viral infection encourage trying it against COVID-19. Artemisinin, an effective anti-malarial drug, reduces tumor necrosis factor (TNF)- $\alpha$ and interleukin (IL)- 6 which are key mediators of acute respiratory distress syndrome (Cheong et al. 2020). In vitro, artemisinin-based combination therapy exerted antiviral activity against clinically isolated SARS-CoV-2 strain (IHUMI-3) in Vero E6 cells; among these, Mefloquine-artesunate showed the best inhibition with $72.1 \pm 18.3 \%$ (Gendrot et al. 2020). A clinical study in China showed that a Hemi-synthetic derivative of artemisinin (artesunate) was accompanied by a shorter duration of COVID-19 symptoms than a standard of care (Cheong et al. 2020; Li et al. 2021) found that the treatment with artemisinin-piperaquine could significantly shorten the time to reach undetectable SARS-CoV-2..

Our survey indicated that Juniperus phoenicea L. subsp.phoenicea is used especially to treat ulcer, diarrhea, gas, eczema, wound, burns, inflammation, and food poisonings. Previous surveys in Algeria have shown that this plant is widely used to treat ulcers, intoxication, inflammation, and digestive disorders (Boudjelal et al. 2013; Bouasla and Bouasla 2017; Miara et al. 2018). Various studies have shown that Amentoflavone isolated from Juniperus phoenicea $L$ exhibit a wide range of pharmacological functions (Yu et al. 2017). Administration of amentoflavone in Wistar rats induced ulcerative colitis reduces the extent of the inflammatory colonic 
injury by decreased mucosal injury score, vascular permeability, and diminished myeloperoxidase and lactate dehydrogenase activity. Furthermore, amentoflavone inhibits colitis by increased superoxide dismutase, glutathione, and decreased lipid peroxidation and nitric oxide. The treatment with this biflavonoid compound reduces the colonic TNF- $\alpha$, IL- $1 \beta$, and IL-6 levels as well as the expression of inducible nitric oxide synthase and cyclooxygenase-2. Also, this compound inhibits the activation and translocation of nuclear factor (NF)- $\mathrm{\kappa B}$ subunits (p65/p50) (Sakthivel and Guruvayoorappan 2013; Yu et al. 2017).

Our respondents have reported that Brocchia cinerea (Delile) Vis could be utilized in the treatment of asthma, allergy, inflammation, hypertension, and eczema. However, the same species was used by the local population and healers in Algeria to treat pharyngitis, cold, stomach ache, kidney diseases, systemic healing, and migraine (Benarba et al. 2015; Benarba 2016). Recent studies revealed that this plant exhibits various biological activities such as analgesic, cytotoxic, and effect on diabetes. These are related to the presence of chemical substances such as flavonoids, terpenes, and essential oils which are predominated by thujone, eucalyptol, and santolinatriene (Amssayef and Eddouks 2020; Guaouguaou et al. 2020). It have been reported that a single and repeated oral administration of Brocchia cinerea (Delile) Vis aqueous extract at the dose of $20 \mathrm{mg} / \mathrm{kg}$ for 15 days, reduced significantly blood glucose and plasma triglycerides levels in both normal and diabetic rats (Amssayef and Eddouks 2020). Other ethnopharmacological uses of the most cited plants by the local population are represented in Table 2.

\section{Fidelity level (FL)}

FL of species was determined and we considered those plants whose FL were superior to 50 as important and significant. The plants with less than 5 use reports were excluded. Ephedra alata subsp. alenda (Stapf) Trab having the highest FL (100\%) was used for treating cancer. The same result was found in the study of Illizi in Algerian Sahara (Miara et al. 2019c). Calculation of FL indicated that Teucrium polium L. is the wide species used for treating digestive disorders with an FL of $60 \%$. Ballota hirsuta Benth has been reported to be used in the treatment of migraine with an FL of (57.14.5\%). Santolina rosmarinifolia $L$ was used for gastric pain having an FL of $56.25 \%$ (Table 2).

\section{Comparison with national and regional ethnobotanical surveys:}

Comparative analysis results from 21 previous ethnobotanical surveys are shown in Table 2; in which they reported at minimum one similar therapeutic use from the inventoried plants. Among the 21 works of literature; 13 can give full data of national surveys or herbal practices in Algeria, the other literature can give the most cited data of ethnobotanical studies or herbal practices in surrounding areas such as Morocco and Italy. The number of medicinal plants listed in different provinces of Algeria ranged from 37 to 141 species. 141 species were recorded in Mascara province (Benarba et al.2015), 118 medicinal herbs were recorded in the Tuareg community in the region of Illizi (Miara et al. 2019c), and 102 medicinal plants were recorded in the two provinces of Constantine and Mila (Ouelbani et al. 2016). While the 37 medicinal plants were recorded in Ouargla province (Ould el-Hadj et al. 2003). Our results inventoried 27 medicinal plants belonged to the four botanical families in Naâma. Two species were newly cited as medicinal plants in our study, and their therapeutic use is not cited in the 21 literature above. The plants were Atractylis caespitosa Desf'and|Nepeta nepetella subsp.amethystina (Poir.) Briq. In Algeria, only one "study has investigated the antimicrobial activity and chemical composition of essential oil'and hydrosol extract of Nepeta nepetella subsp. amethystina (Poir.) Briq (Bellahsene et al. 2015). These results can contribute to new research for further biological and pharmacological studies?.

Some new therapeutic uses that did not mention to those in the previous studies are recorded in our study. Species used to treat brucellosis such asłArtemisia campestris L.; species used as anti-inflammatories like Brocchia cinerea (Delile) Vis, Thymus algeriensis Boiss. \& Reut, and Thymus munbyanus subsp. ciliatus (Desf.) Greuter \& Burdet; and species lused to manage hypercholesterolemia included'Thymus algeriensis Boiss. \& Reut. Other new practices were described for Maropsis deserti (de Noé) Pomel as a diuretic while Rhanterium adpressum Coss. \& Durieu as antidiuretic; Otoglyphis pubescens (Desf.) Pomel to treat otitis and tonsillitis; Saccocalyx satureioides Coss. \& Durieu as antihypertensive; Ballota hirsuta Benth to heal rheumatism. For skin diseases; the new uses referred to Brocchia cinerea (Delile) Vis to treat eczema. The same plant with Anvillea garcinii subsp. radiata (Coss. \& Durieu) Anderb acts as an anti-allergic plant; Ephedra alata subsp. alenda (Stapf) Trab using as an anti-goiter;' Juniperus oxycedrus L. subsp.oxycedrus and Santolina rosmarinifolia L. as anti-ulcer agents. Also, the new traditional therapeutics that did not cite any in the previous literature included Artemisia herba-alba Asso, and Thymus algeriensis Boiss. \& Reut to manage COVID-19 symptoms. These botanical species should be evaluated phytochemically and pharmaceutically.

\section{Conclusions}

The current study is the first survey that records the indigenous knowledge of the use of medicinal plants in the province of Naâma. The results obtained indicate the richness 
and diversity of the area with medicinal plants. Moreover, local people possess precious quantities of knowledge confirmed by the large number of species cited with their mode of preparation and different part used for manifold therapeutic uses. Some of this heritage was being lost. That is why; this study supports the importance of the preservation of local knowledge and indigenous practices of transferring it to other communities and scientists. It became necessary that the pharmaceutical industry must collaborate with the indigenous traditional people's possessed collective knowledge of alternative medicine as a source of new drugs.

Acknowledgements The authors are grateful to the peoples of Naâma for accepting to share their knowledge and practices. Without their contribution, this study would have been impossible.

Code availability Not applicable.

\section{Declarations}

Conflict of interest The authors declare no conflict of interest.

\section{References}

Abouri M, El Mousadik A, Msanda F et al (2012) An ethnobotanical survey of medicinal plants used in the Tata Province, Morocco. Int J Med Plant Res 1:99-123

Amssayef A, Eddouks M (2020) Antihyperglycemic, antihyperlipidemic and antioxidant effects of cotula cinerea (del) in normal and streptozotocin-induced diabetic rats. Endocr Metab Immune Disord Drug Targets 20:1. https://doi.org/10.2174/1871530320 666200513081312

Aziz M, Karim A, El-Ouariachi EM et al (2012) Relaxant effect of essential oil of Artemisia herba-alba Asso. on rodent jejunum contractions. Sci Pharm 80:457-467. https://doi.org/10.3797/ scipharm.1106-13

Bellahsene C, Bendahou M, Khadir A et al (2015) Antimicrobial activity and chemical composition of essential oil and hydrosol extract of Nepeta nepetella subsp. amethystina (Poir.) Briq. from Algeria. J Appl Pharm Sci 5:21-25. https://doi.org/10.7324/JAPS.2015. 50904

Benarba B (2016) Medicinal plants used by traditional healers from south-west Algeria: an ethnobotanical study. J Intercult Ethnopharmacol 5:320-330. https://doi.org/10.5455/jice.2016081411 5725

Benarba B, Belabid L, Righi K et al (2015) Ethnobotanical study of medicinal plants used by traditional healers in Mascara (North West of Algeria). J Ethnopharmacol 175:626-637. https://doi.org/ 10.1016/j.jep.2015.09.030

Bouasla A, Bouasla I (2017) Ethnobotanical survey of medicinal plants in northeastern of Algeria. Phytomedicine 36:68-81. https://doi. org/10.1016/j.phymed.2017.09.007

Boudjelal A, Henchiri C, Sari M et al (2013) Herbalists and wild medicinal plants in M'Sila (North Algeria): an ethnopharmacology survey. J Ethnopharmacol 148:395-402. https://doi.org/10. 1016/j.jep.2013.03.082

Bouzabata A (2017) Les médicaments à base de plantes en Algérie: réglementation et enregistrement. Phytothérapie 15:401-408. https://doi.org/10.1007/s10298-016-1089-5
Cheong DHJ, Tan DWS, Wong FWS, Tran T (2020) Anti-malarial drug, artemisinin and its derivatives for the treatment of respiratory diseases. Pharmacol Res 158:104901. https://doi.org/10. 1016/j.phrs.2020.104901

Eddouks M, Maghrani M, Lemhadri A, Ouahidi M-L, Jouad H (2002) Ethnopharmacological survey of medicinal plants used for the treatment of diabetes mellitus, hypertension and cardiac diseases in the south-east region of Morocco (Tafilalet). J Ethnopharmacol 82:97-103. https://doi.org/10.1016/S03788741(02)00164-2

Eddouks M, Ajebli M, Hebi M (2017) Ethnopharmacological survey of medicinal plants used in Daraa-Tafilalet region (Province of Errachidia), Morocco. J Ethnopharmacol 198:516-530. https:// doi.org/10.1016/j.jep.2016.12.017

Fakchich J, Elachouri M (2021) An overview on ethnobotanico-pharmacological studies carried out in Morocco from 1991 to 2015: Systematic review (part 1). J Ethnopharmacol 267:113200. https:// doi.org/10.1016/j.jep.2020.113200

Gendrot M, Duflot I, Boxberger M et al (2020) Antimalarial artemisinin-based combination therapies (ACT) and COVID-19 in Africa: in vitro inhibition of SARS-CoV-2 replication by mefloquine-artesunate. Int J Infect Dis. https://doi.org/10.1016/j.ijid. 2020.08.032

Guaouguaou FE, Bebaha MAA, Taghzouti K, Es-Safi NE (2020) Phytochemical investigation, acute toxicity, central analgesic and antioxidant activities of extracts and essential oil of Cotula cinerea Del (Asteraceae). Curr Bioact Compd 16:164-173. https://doi.org/ 10.2174/1573407214666180821115826

Hammiche V, Maiza K (2006) Traditional medicine in Central Sahara: pharmacopoeia of Tassili N'ajjer. J Ethnopharmacol 105:358367. https://doi.org/10.1016/j.jep.2005.11.028

Hamza N, Berke B, Umar A et al (2019) A review of Algerian medicinal plants used in the treatment of diabetes. J Ethnopharmacol 238:111841. https://doi.org/10.1016/j.jep.2019.111841

Jamila F, Mostafa E (2014) Ethnobotanical survey of medicinal plants used by people in Oriental Morocco to manage various ailments. J Ethnopharmacol 154:76-87. https://doi.org/10.1016/j.jep.2014. 03.016

Kefifa A, Saidi A, Hachem K, Mehalhal O (2018) An ethnobotanical survey and quantitative study of indigenous medicinal plants used in the Algerian semi-arid region. Phytothérapie. https://doi.org/ 10.3166/phyto-2018-0077

Kharchoufa L, Merrouni IA, Yamani A, Elachouri M (2018) Profile on medicinal plants used by the people of north Eastern Morocco: toxicity concerns. Toxicon 154:90-113. https://doi.org/10.1016/j. toxicon.2018.09.003

Khlifi D, Sghaier RM, Amouri S et al (2013) Composition and antioxidant, anti-cancer and anti-inflammatory activities of Artemisia herba-alba, Ruta chalpensis L. and Peganum harmala L. Food Chem Toxicol 55:202-208. https://doi.org/10.1016/j.fct.2013. 01.004

Lahsissene H, Kahouadji A (2010) Analyse ethnobotanique des plantes médicinales et aromatiques de la flore marocaine: cas de la région de Zaër 1. Phytothérapie 8:202-209. https://doi.org/10. 1007/s10298-010-0569-2

Li G, Yuan M, Li H et al (2021) Safety and efficacy of artemisininpiperaquine for treatment of COVID-19: an open-label, non-randomised and controlled trial. Int J Antimicrob Agents 57:106216. https://doi.org/10.1016/j.ijantimicag.2020.106216

Marrif HI, Ali BH, Hassan KM (1995) Some pharmacological studies on Artemisia herba-alba (Asso.) in rabbits and mice. J Ethnopharmacol 49:51-55. https://doi.org/10.1016/0378-8741(95)01302-4

Meriem E, Hayet E (2019) Are the plants used in Algerian traditional medicine effective?: Assessment of the antibacterial, anti-inflammatory and anti-oxidative effects of three plants used in Algerian traditional medicine; Olea europaea, Glycyrrhiza glabra and 
Ocimum basilicum. Med Technol J 3:443-452. https://doi.org/10. 26415/2572-004X-vol3iss3p443-452

Miara MD, Hammou MA, Aoul SH (2013) Phytothérapie et taxonomie des plantes médicinales spontanées dans la région de Tiaret (Algérie). Phytotherapie 11:206-218. https://doi.org/10.1007/ s10298-013-0789-3

Miara MD, Bendif H, Ait Hammou M, Teixidor-Toneu I (2018) Ethnobotanical survey of medicinal plants used by nomadic peoples in the Algerian steppe. J Ethnopharmacol 219:248-256. https:// doi.org/10.1016/j.jep.2018.03.011

Miara MD, Bendif H, Rebbas K et al (2019a) Medicinal plants and their traditional uses in the highland region of Bordj Bou Arreridj (Northeast Algeria). J Herb Med 16:100262. https://doi.org/10. 1016/j.hermed.2019.100262

Miara MD, Bendif H, Ouabed A et al (2019b) Ethnoveterinary remedies used in the Algerian steppe: Exploring the relationship with traditional human herbal medicine. J Ethnopharmacol 244:112164. https://doi.org/10.1016/j.jep.2019.112164

Miara MD, Teixidor-Toneu I, Sahnoun T, Bendif H, Ait Hammou M (2019c) Herbal remedies and traditional knowledge of the Tuareg community in the region of Illizi (Algerian Sahara). J Arid Environ 167:65-73. https://doi.org/10.1016/j.jaridenv.2019.04.020

Mohamed HRH, Amer M, Faky ASAE (2019) Growth retardation and apoptotic death of tumor cells by Artemisia herba-alba oral administration in Ehrlich solid carcinoma bearing mice. Rev Bras Farmacogn 29:763-772. https://doi.org/10.1016/j.bjp.2019.06.007

Ouelbani R, Bensari S, Mouas TN, Khelifi D (2016) Ethnobotanical investigations on plants used in folk medicine in the regions of Constantine and Mila (North-East of Algeria). J Ethnopharmacol 194:196-218. https://doi.org/10.1016/j.jep.2016.08.016

Ould el-Hadj M, Hadj-Mahammed M, Zabeirou H (2003) Place des plantes spontanées dans la médicine traditionnelle de la région de Ouargla (Sahara septentrional est). Courr du Savoir 3:47-51

Phillips OL (1996) Some quantitative methods for analyzing ethnobotanical knowledge. Advances in economic botany. JSTOR, Berlin, pp 171-197

Réggami Y, Benkhaled A, Boudjelal A et al (2019) Artemisia herbaalba aqueous extract improves insulin sensitivity and hepatic steatosis in rodent model of fructose-induced metabolic syndrome. Arch Physiol Biochem. https://doi.org/10.1080/13813455.2019. 1659825

Rodríguez-Calderón Á, Muñoz JA, Moreno D, Celis M (2019) Describing and diffusing the ethnobotanical knowledge of Bogotá D.C.
(Colombia) through an online tool focused on common names of plants. Acta Bot Bras 33:303-314. https://doi.org/10.1590/0102$33062018 \mathrm{abb} 0337$.

Saad B, Said O (2010) Tradition and Perspectives of Greco-Arab and Islamic Herbal Medicine. Herb Suppl. https://doi.org/10.1002/ 9780470910108.ch10

Sakthivel KM, Guruvayoorappan C (2013) Amentoflavone inhibits iNOS, COX-2 expression and modulates cytokine profile, NF- $\mathrm{\kappa B}$ signal transduction pathways in rats with ulcerative colitis. Int Immunopharmacol 17:907-916. https://doi.org/10.1016/j.intimp. 2013.09.022

Seow CL, Lau AJ (2017) Differential activation of pregnane X receptor by carnosic acid, carnosol, ursolic acid, and rosmarinic acid. Pharmacol Res 120:23-33. https://doi.org/10.1016/j.phrs.2017.03.007

Tomi K, Kitao M, Konishi N et al (2016) Enantioselective GC-MS analysis of volatile components from rosemary (Rosmarinus officinalis L.) essential oils and hydrosols. Biosci Biotechnol Biochem 80:840-847. https://doi.org/10.1080/09168451.2016.1146066

Trotter RT, Logan MH (1986) Informant consensus: a new approach for identifying potentially effective medicinal plants. In: Etkin NL (ed) Plants and indigenous medicine and diet, biobehavioral approaches, vol 1. Routledge, New York, p 91-112

Tuttolomondo T, Licata M, Leto C et al (2014) Ethnobotanical investigation on wild medicinal plants in the Monti Sicani Regional Park (Sicily, Italy). J Ethnopharmacol 153:568-586. https://doi.org/10. 1016/j.jep.2014.02.032

WHO (World Health Organization) (2001) Legal status of traditional medicine and complementary/alternative medicine: a worldwide review. No.WHO/EDM/TRM/2001.2, Geneva

Yu S, Yan H, Zhang L et al (2017) A review on the phytochemistry, pharmacology, and pharmacokinetics of amentoflavone, a naturally-occurring biflavonoid. Molecules 22:299. https://doi.org/10. 3390/molecules22020299

Zeggwagh NA, Farid O, Michel JB, Eddouks M (2008) Cardiovascular effect of Artemisia herba alba aqueous extract in spontaneously hypertensive rats. Methods Find Exp Clin Pharmacol 30:375. https://doi.org/10.1358/mf.2008.30.5.1186081

Publisher's Note Springer Nature remains neutral with regard to jurisdictional claims in published maps and institutional affiliations. 